\title{
Final call for papers: "Towards a scaling-up of training and education for health workers" Daniel MP Shaw
}

Address: Department of Human Resources for Health, Health Systems and Services, World Health Organization, 20 Avenue Appia, Geneva, Switzerland

Email: Daniel MP Shaw - shawd@who.int

Published: II September 2007

Human Resources for Health 2007, 5:22 doi:10.1 186/1478-4491-5-22
Received: 31 August 2007

Accepted: II September 2007

This article is available from: http://www.human-resources-health.com/content/5/I/22

(c) 2007 Shaw; licensee BioMed Central Ltd.

This is an Open Access article distributed under the terms of the Creative Commons Attribution License (http://creativecommons.org/licenses/by/2.0), which permits unrestricted use, distribution, and reproduction in any medium, provided the original work is properly cited.

\section{Joint call for papers for special issue of the} journals

- Human Resources for Health http://www.humanresources-health.com

- American Journal of Public Health http://www.ajph.org

- Archives of Iranian Medicine http://www.ams.ac.ir/AIM/ index.html

- Croatian Medical Journal http://www.cmj.hr

- Education for Health http://www.educationfor health.net

- International Nursing Review http://www.blackwellpub lishing.com/inr

- Leadership in Health Services http://www.ingentacon nect.com/content/mcb/211

- Journal of the Brazilian Association of Medical Schools

- New Zealand Medical Journal http://www.nzma.org.nz/ journal

- Nursing Ethics http://www.sagepub.co.uk

- Online Brazilian Journal of Nursing http://www.uff.br/ objnursing

- Open Medicine http://www.openmedicine.ca
- Papua New Guinea Medical Journal http:// www.pngimr.org.pg/medicaljournals.htm

- PLoS Medicine http://www.plosmedicine.org

- Progress in Community Health Partnerships http:// pchp.press.jhu.edu

- Public Health http://intl.elsevierhealth.com/journals/ pubh/

- South African Medical Journal http://www.jour nals.co.za/sama/m_samj.html

- Sudanese Journal of Public Health http:// www.sjph.net.sd

WHO Human Resources for Health are leading an international joint special issue which is now accepting papers for joint special issues addressing the critical need for a skilled, sustainable health workforce in the developing world. Submitted articles must fall under the broad theme:

"Towards a scaling-up of training and education for health workers"

The World Health Report 2006: Working together for health, recognized the centrality of the health workforce for the effective operation of country health systems and outlined proposals to tackle a global shortage of 4.3 million health workers. There is increasing evidence that that this shortage is interfering with efforts to achieve international 
development goals, including those contained in the Millenium Declaration and those of WHO's priority programmes.

The health workforce crisis in developing countries derives principally from inadequate educational opportunities for health workers and a lack of relevance of their training to community health care practice. Additional contributing factors include: inadequate compensation and working conditions, the deteriorating health of the workforce in many developing countries, urban/rural and workforce imbalance, and migration of the workforce from developing to developed countries.

We are seeking manuscripts concerned with the scalingup of training and education for health workers. Possible sub-themes include, but are not limited to:

- private sector engagement

- regulatory frameworks for education and practice

- labour market dynamics after the production of health workers (e.g. retention)

- training teams rather than individuals

- skills mix

- multi-skilled workers, responsive to exiting needs

- task-shifting/role substitution

- competency-based education and training

Examples of questions that could be considered are:

- What ongoing efforts to increase graduate level primary care training have been established in developing countries. What has been their impact and what have been their problems?

-What effective strategies have been developed and tested for customizing the workforce skill mix to local health service needs? For example, what impact have recent health sector reforms had on the local health workforce?

- What is the status of existing efforts to train health workers using innovative methods, including distance learning and various forms of information technology? How will training by protocol differ from, and complement, traditional community health worker training?
- How can the health professional training be better aligned with local health needs and be more socially accountable?

- What is the status of existing collaborations between developing countries aiming to improve health worker education?

- How have modifications in healthcare management had an impact upon health workforce capacity at the local level?

Papers will be accepted in two formats:

Full papers of 3000 words or less for policy and research papers

Brief communications of less than 1200 words: better suited to program or project descriptions or commentaries.

Planned publication will be for a period of several months, starting from June 2008. There will be an online facility to respond to published articles in order to accommodate a live debate.

If you would like to submit either an article or brief, please send us a provisional title and a short outline of the major topics you would address.

Proposals for manuscripts are due by 15 September 2007 and should be submitted by e-mail to hrhspecial@who.int. Instructions for submission of articles will then be provided with feedback. Final manuscripts are due by 30 November 2007.

Publish with Bio Med Central and every scientist can read your work free of charge

"BioMed Central will be the most significant development for disseminating the results of biomedical research in our lifetime. " Sir Paul Nurse, Cancer Research UK

Your research papers will be:

- available free of charge to the entire biomedical community

- peer reviewed and published immediately upon acceptance

- cited in PubMed and archived on PubMed Central

- yours - you keep the copyright

Submit your manuscript here:

http://www.biomedcentral.com/info/publishing_adv.asp
BioMedcentral 